\title{
Low-temperature synthesis of zeolite from perlite waste - Part I: review of methods and phase compositions of resulting products
}

\author{
Magdalena KróL*, Justyna MoraWska, WŁodzimierz MozgaWa, Waldemar Pichór \\ Faculty of Materials Science and Ceramic, AGH University of Science and Technology, \\ 30 Mickiewicza Av., 30-059 Krakow, Poland
}

\begin{abstract}
In this paper a review of the recent studies on the synthesis of zeolites from expanded perlite under hydrothermal conditions is presented. Attention is paid to possible outcomes of synthesis from low cost glass material, such as perlite. The study also investigates the phase composition of zeolitic materials obtained by modification of by-product derived from an expanded perlite production process. The synthesis was made using the hydrothermal method with sodium hydroxide under autogenous pressure at a temperature below $100{ }^{\circ} \mathrm{C}$ for 1 to $72 \mathrm{~h}$. It was possible to obtain a zeolitic material at a temperature as low as $60{ }^{\circ} \mathrm{C}$ using 4.0 M NaOH. The X-ray diffraction pattern showed the biggest peak intensity of zeolite X with $4.0 \mathrm{M} \mathrm{NaOH}$ at the temperature of $70{ }^{\circ} \mathrm{C}$. During synthesis at higher temperature zeolite $\mathrm{Na}-\mathrm{P}_{1}$ (with $3.0 \mathrm{M} \mathrm{NaOH}$ at $90{ }^{\circ} \mathrm{C}$ ) and hydroxysodalite (with $5.0 \mathrm{M} \mathrm{NaOH}$ at $90{ }^{\circ} \mathrm{C}$ ) were obtained.
\end{abstract}

Keywords: synthesis of zeolites; zeolite X; expanded perlite waste; FT-IR spectra

(C) Wroclaw University of Technology.

\section{Introduction}

Zeolites are a group of tectoaluminosilicates characterized by unique physical and chemical properties. They have many important applications. The properties of zeolites arise directly from their specific structure, which is characterized by spatial aluminosilicate framework built from channels and cages that have clearly defined molecular dimensions [1]. Among other things, thermal stability, chemical resistance, very good catalytic properties, molecular sieve, ion exchange, sorption capacity, and so on, caused that these minerals found numerous applications in chemical technology [2] and their importance is increasing.

Natural zeolites occur in crystalline forms found in igneous and metamorphic rocks and as accumulated in sedimentary rocks grains with smaller diameters [3]. However, zeolites can also be obtained under laboratory conditions. The oldest works on the synthesis of silicates under hydrother-

*E-mail: mkrol@agh.edu.pl mal conditions dates back to the 50's of the last century [4]. By heating aluminosilicate raw materials in the presence of alkaline solutions, final product can be obtained within a few hours or days, depending on the type of raw materials and process conditions (temperature, pressure). Synthesis parameters and products obtained from different volcanic gasses are collected in Table 1.

Type of zeolite structure, which is formed at a given temperature, depends largely on the composition of the starting mixture. However, process parameters, such as $\mathrm{pH}$ of the reaction solution, temperature, pressure and treatment time as well as the degree of fineness or mixing of reagents and other factors, affect the crystallization in systems having the same chemical composition [5]. Some properties of products can be controlled during synthesis, for example, the type of structure, the $\mathrm{SiO}_{2} / \mathrm{Al}_{2} \mathrm{O}_{3}$ molar ratio, and pore size or density of the framework.

Various silica carriers, including natural materials, such as kaolinite, volcanic glasses (perlite, pumice), rice husks, diatomite as well as 
Table 1. List of previous investigations on the synthesis of zeolites from perlite and other volcanic glasses.

\begin{tabular}{|c|c|c|c|c|c|c|c|}
\hline \multirow{2}{*}{$\begin{array}{l}\text { Starting } \\
\text { material }\end{array}$} & \multicolumn{5}{|c|}{ Analyzed synthesis parameters } & \multirow{2}{*}{ - Products } & \multirow{2}{*}{ Ref. } \\
\hline & $\begin{array}{c}\text { Solution } \\
{\left[\mathrm{mol}^{\prime} \mathbf{d m}^{3}\right]}\end{array}$ & $\begin{array}{c}\mathrm{SiO}_{2} / \mathrm{Al}_{2} \mathrm{O}_{3} \\
\text { mol. ratio }\end{array}$ & $\begin{array}{c}\mathrm{S} / \mathrm{L} \\
{[\mathrm{g} / \mathrm{ml}]}\end{array}$ & $\begin{array}{l}\text { Temp. } \\
{\left[{ }^{\circ} \mathrm{C}\right]}\end{array}$ & $\begin{array}{c}\text { Time } \\
{[\mathrm{h}]}\end{array}$ & & \\
\hline expanded perlite & $0.5-4.0 \mathrm{M} \mathrm{NaOH}$ & & $1: 13-56$ & $100-140$ & $2-312$ & $\begin{array}{l}\text { analcime, zeolite } \\
\text { Na- } \mathrm{P}_{c}, \text { hydroxysodalite, } \\
\text { zeolite A }\end{array}$ & [13] \\
\hline natural perlite & $3 \mathrm{M} \mathrm{NaOH}$ & & $1: 5$ & 140 & 24 & analcime & {$[14]$} \\
\hline natural perlite & $1-4 \mathrm{M} \mathrm{NaOH}$ & $1-40$ & 15 & 140,170 & 2 & $\begin{array}{l}\text { zeolite } \mathrm{Na}-\mathrm{P}_{1}, \\
\text { hydroxysodalite }\end{array}$ & {$[15]$} \\
\hline natural perlite & $1-3 \mathrm{M} \mathrm{NaOH}$ & & $1: 5-20$ & $100-140$ & $24-168$ & $\begin{array}{l}\text { analcime, zeolite } \\
\mathrm{Na}-\mathrm{P}_{1}, \text { cancrinite }\end{array}$ & {$[16,19]$} \\
\hline natural perlite & $1-5 \mathrm{M} \mathrm{NaOH}$ & 9.12 & $1: 5-30$ & $100-140$ & $2-4$ & $\begin{array}{l}\text { zeolite } \mathrm{P}_{c} \text {, zeolite } \mathrm{V}, \\
\text { hydroxysodalite }\end{array}$ & {$[18]$} \\
\hline natural perlite & $1-3 \mathrm{M} \mathrm{NaOH}$ & & $1: 5$ & $70-100$ & $120-480$ & $\begin{array}{l}\text { phillipsite, zeolite Y, } \\
\text { hydroxysodalite }\end{array}$ & {$[20]$} \\
\hline natural perlite & $5 \mathrm{M} \mathrm{NaOH}$ & $5-11.54$ & $1: 5$ & $70-110$ & 48 & $\begin{array}{l}\text { zeolite } \mathrm{Y}, \\
\text { hydroxysodalite, } \\
\text { zeolite } \mathrm{Na}-\mathrm{P}_{1}\end{array}$ & {$[22]$} \\
\hline natural perlite & $5 \mathrm{M} \mathrm{NaOH}$ & 9.12 & $1: 5$ & 120 & 2 & zeolite Y & [21] \\
\hline $\begin{array}{l}\text { natural perlite, } \\
\text { expanded perlite }\end{array}$ & $2 \mathrm{M} \mathrm{NaOH}$ & 9.12 & $1: 10$ & 120 & 2 & zeolite A, zeolite X & {$[23,24]$} \\
\hline pumice & $5 \mathrm{M} \mathrm{NaOH}$ & & $1: 5$ & 95 & 5 & $\begin{array}{l}\text { phillipsite, } \\
\text { Hydroksysodalit, } \\
\text { zeolite Y }\end{array}$ & [25] \\
\hline expanded perlite & $0.5-6.0 \mathrm{M} \mathrm{KOH}$ & & $1: 20$ & $100-140$ & $2-312$ & $\begin{array}{l}\text { filipsyd, merlinoitee, } \\
\text { chabazite, edingtonite }\end{array}$ & [13] \\
\hline rhyolitic glass & $1 \mathrm{M} \mathrm{CaCl}_{2}$ & & $3: 1$ & $130-240$ & 192 ( $1-9$ cycles $)$ & $\begin{array}{l}\text { gismondine, calcite, } \\
\text { tobermorite, heulandite, } \\
\text { epistilbite }\end{array}$ & [11] \\
\hline rhyolitic glass & $0.8-3 \mathrm{M} \mathrm{Na}_{2} \mathrm{CO}_{3}$ & & $3: 1$ & $110-240$ & $24-240$ & $\begin{array}{l}\text { zeolite } \mathrm{P}_{1} \text {, analcime, } \\
\text { mordenite }\end{array}$ & [11] \\
\hline obsidian & $\begin{array}{l}0.001-0.5 \mathrm{M} \mathrm{NaOH} \\
0.001-0.5 \mathrm{M} \mathrm{KOH}\end{array}$ & & $1: 25$ & 150,200 & $24-720$ & $\begin{array}{l}\text { phillipsite, } \\
\text { merlinoite }\end{array}$ & [26] \\
\hline volcanic glass & $\begin{array}{l}0.2-2.0 \mathrm{M} \mathrm{Na}_{2} \mathrm{CO}_{3}+ \\
0.2-2.0 \mathrm{~K}_{2} \mathrm{CO}_{3}\end{array}$ & & & $115-150$ & $48-384$ & $\begin{array}{l}\text { phillipsite, } \\
\text { clinoptilolite, } \\
\text { mordenite }\end{array}$ & [27] \\
\hline perlite, pumice & $\mathrm{NaOH}$ & & $1: 5$ & 85,95 & 5 & $\begin{array}{l}\text { phillipsite, } \\
\text { clinoptilolite, } \\
\text { mordenite }\end{array}$ & [28] \\
\hline $\begin{array}{l}\text { rhyolitic glass, } \\
\text { basaltic glass, } \\
\text { oligoclase, } \\
\text { nepheline }\end{array}$ & $\begin{array}{l}0.1 \mathrm{M} \text { and } 0.01 \mathrm{M} \\
\mathrm{CaCl}_{2} \\
0.01 \mathrm{M} \mathrm{CaCl}_{2}+\mathrm{NaOH}\end{array}$ & & & $150-250$ & $8-120$ & $\begin{array}{l}\text { heulandite, phillipsite, } \\
\text { epistilbite, wairakite }\end{array}$ & [33] \\
\hline rhyolitic glass & $0.8 \mathrm{M} \mathrm{Na}_{2} \mathrm{CO}_{3}$ & $3.0-3.2$ & $1: 20$ & 120 & 264 & zeolite Na-P 1 & [34] \\
\hline
\end{tabular}


synthetic silicates, are used in zeolite synthesis [6]. The environmental aspect, which involves the use of waste materials, shapes the current trends in research on the synthesis of zeolites [7]. Also the use of natural raw materials for the production of zeolites has economic advantages when compared with the use of synthetic subtracts.

Perlite is a naturally occurring volcanic rock. It is characterized by an amorphous structure. It contains a large amount of bound water (2 to $6 \%$ ). Rapid heating of perlite to the temperature of $870{ }^{\circ} \mathrm{C}$ causes evaporation of water and formation of an expanded structure [8,9]. Expanded perlite has a very high bulk density and vesicular structure, which results in a multitude of applications [1, 3]. However, expanded perlite waste (subgrain) is formed in the production process, which due to the high volatility is very difficult to store. This waste is a source of reactive silica and therefore can be used in the synthesis of zeolites.

Zeolitization of volcanic glass in a humid atmosphere and in the temperature range of 75 to $250{ }^{\circ} \mathrm{C}$ occurs spontaneously, but the process is very long $[10,11]$. In the laboratory zeolites are synthesized at temperatures below $200{ }^{\circ} \mathrm{C}$, most commonly using $\mathrm{NaOH}$ (or $\mathrm{Na}_{2} \mathrm{CO}_{3}$ ) solutions. Scientific and patent literature in the field of the synthesis of zeolites from waste materials lists a number of factors influencing the type and purity of the products. Among the most important are: time, temperature and pressure of the process, the chemical composition of the reaction mixture prior to crystallization (usually expressed as the $\mathrm{SiO}_{2} / \mathrm{Al}_{2} \mathrm{O}_{3}$ and $\mathrm{Na}_{2} \mathrm{O} / \mathrm{SiO}_{2}$ molar ratios) and the concentration of reactants [12]. Using perlite as the starting material for the synthesis of zeolites on laboratory scale has been the subject of numerous papers. Zeolites possible to obtain are as follows: hydroxysodalite, analcime, zeolite $\mathrm{A}$, zeolite $\mathrm{X}$ and zeolite $\mathrm{Na}-\mathrm{P}_{1}$ as well as phillipsite, merlinoite, chabazite, edingtonite and also epistilbite or heulandite [11, 13-17].

Zeolite Na- $\mathrm{P}_{1}$ (gismondite type structure) is the most stable product of the synthesis carried out at $100{ }^{\circ} \mathrm{C}$ for 1 to 4 days $[11,15]$. At higher temperatures zeolite Na-P $\mathrm{P}_{1}$ tends to transform into analcime [15, 17], however, its quantity and degree of crystallinity depends on the time of synthesis. Phase diagrams of zeolite synthesized at 140 and $170{ }^{\circ} \mathrm{C}$ from perlite depending on the $\mathrm{NaOH}$ concentration and the $\mathrm{SiO}_{2} / \mathrm{Al}_{2} \mathrm{O}_{3}$ ratio were developed [15]. To adjust the $\mathrm{SiO}_{2} / \mathrm{Al}_{2} \mathrm{O}_{3}$ ratio, rice husk ash (a source of amorphous silica) and $\mathrm{AlCl}_{3} \cdot 6 \mathrm{H}_{2} \mathrm{O}$ were used. Analcime is formed in virtually all conditions, with the exception of the $\mathrm{NaOH}$ concentration less than $1.5 \mathrm{M} / \mathrm{dm}^{3}$ and $\mathrm{SiO}_{2} / \mathrm{Al}_{2} \mathrm{O}_{3}$ ratio below 25. Zeolite Na- $\mathrm{P}_{1}$ is formed over the range of analyzed conditions, with the exception of high concentrations of $\mathrm{NaOH}$ and a high $\mathrm{SiO}_{2} / \mathrm{Al}_{2} \mathrm{O}_{3} \mathrm{ra}-$ tio, when analcime and hydroxysodalite is formed. The latter presumably tends to be formed at high concentrations of $\mathrm{NaOH}$ [18]. A higher temperature, in turn, promotes the formation of analcime $[4,15,19]$.

Depending on the process parameters, particularly temperature, it is possible to obtain also other zeolite phases. There is a tendency to try to lower the temperature of the process, with the simultaneous desire to obtain clearly defined, preferably a single-phase product. At relatively low temperatures, in the range of 70 to $100{ }^{\circ} \mathrm{C}$, selective synthesis of phillipsite and hydroxysodalite from volcanic glass is possible [20]. At lower $\mathrm{NaOH}$ concentrations (below $3 \mathrm{M}$ ), regardless of the time of synthesis, pure phillipsite is formed. In contrast, it was found that it is impossible to obtain zeolite $\mathrm{Y}$, as an independent phase, in any of the analyzed cases it coexisted with phillipsite [18]. Synthesis time significantly affects the formation of zeolite Y: its extension results in the transformation into zeolite $\mathrm{Na}-\mathrm{P}_{1}$ [21]. The largest quantities ( $\sim 30$ wt.\%) can be obtained at $90{ }^{\circ} \mathrm{C}$ after 2 days using a $\mathrm{SiO}_{2} / \mathrm{Al}_{2} \mathrm{O}_{3}$ molar ratio equal to 6 and the $\mathrm{NaOH}$ concentration: $5 \mathrm{M} / \mathrm{dm}^{3}$ [22].

Conditions for the synthesis of zeolite A are also quite well known. Its synthesis occurs in a short time even at low temperatures (below $100{ }^{\circ} \mathrm{C}$ ), however, its synthesis requires an appropriate composition of the reaction mixture. Application to the synthesis of a silica-rich material (like perlite) requires the introduction of an additional carrier of aluminum. The addition of nucleating agents as well as $\mathrm{NaCl}$ favors the 
crystallization [13]. Detailed analysis of the crystallization process showed [23] that the zeolite A is an intermediate in the synthesis of stable zeolite $\mathrm{X}$. This phase can be obtained after just one hour synthesis from the reaction mixture having a $\mathrm{SiO}_{2} / \mathrm{Al}_{2} \mathrm{O}_{3}$ molar ratio $<3[23,24]$.

Analysis of above data indicates a tendency of reaction systems to create compact structures. The structural density of the product increases with increasing temperature and the time of synthesis. Among zeolites composed of the same structural units (e.g. sodalite cage) a tendency to transform, in the order: zeolite $\mathrm{A} \rightarrow$ zeolite $\mathrm{X}(\mathrm{Y}) \rightarrow$ sodalite, is observed. It was found that the $\mathrm{S} / \mathrm{L}$ ratio (solid to liquid ratio) does not significantly affect the type of resulting phases, while a temperature, pressure, solution concentration and $\mathrm{SiO}_{2} / \mathrm{Al}_{2} \mathrm{O}_{3}$ ratio are determining factors [18]. The latter parameter is crucial: $\mathrm{Si} / \mathrm{Al}$ ratio of product is similar to, or lower than $\mathrm{Si} / \mathrm{Al}$ ratio of starting material [1]. In addition, it has been shown that synthesis using a material with high iron content gives a product with a lower proportion of silicon in the structure [25]. Also the presence of anions in the reaction system can influence the type of the resulting phases [2].

Synthesis of zeolites takes place in an alkaline medium, wherein, as already mentioned, most of the work focuses on using sodium-rich solutions $\left(\mathrm{NaOH}\right.$ or $\left.\mathrm{NaCO}_{3}\right)$. There are only few studies that use other solutions $[13,26]$. It was found [13] that in a closed system at a temperature in the range of 100 to $140{ }^{\circ} \mathrm{C}$ in a $\mathrm{KOH}$ solution during 2 hours to 13 days there arise: phillipsite, merlinoite, chabazite and edingtonite, while in the $\mathrm{NaOH}$ solution, under the same conditions, analcime, zeolite Na- $\mathrm{P}_{1}$, hydroxysodalite and zeolite $\mathrm{A}$ are crystallized. Phillipsite arises only from a silica-rich mixture at a relatively low $\mathrm{pH}$, and essential in its crystallization is a $\mathrm{Na} / \mathrm{K}$ ratio (it arises only in the presence of $\mathrm{K}^{+}$ions, but the presence of $\mathrm{Na}^{+}$ions favors its formation). Similarly, merlinoite can be synthesized from perlite without the addition of alumina, but at higher concentrations of $\mathrm{KOH}$ [13]. Edingtonite and chabazite are rather formed at low temperatures, wherein edingtonite arises only at high concentrations of $\mathrm{KOH}$ [13]. In addition, the media of aluminum type, used as additives for adjusting the $\mathrm{Si} / \mathrm{Al}$ ratio, do not affect the type of resulting product [13].

Phillipsite is thermodynamically unstable and should behave as an intermediate in the synthesis of clinoptilolite and then mordenite [27]. It was found that phillipsite may be formed at temperatures lower than $150{ }^{\circ} \mathrm{C}$ in the presence of $\mathrm{K}^{+}$ions and during one week. Longer synthesis time promotes the formation of clinoptilolite, while mordenite is formed at temperatures higher than $140{ }^{\circ} \mathrm{C}$ from sodium-rich solutions. However, as above, the $\mathrm{SiO}_{2} / \mathrm{Al}_{2} \mathrm{O}_{3}$ ratio is the most important factor determining the nature of the crystallized phases in such a system [28].

Only few papers deal with the study of zeolites synthesis at low temperature, i.e. $<100{ }^{\circ} \mathrm{C}[20,22$, $25,28]$. It was found that as the result of direct reaction with $\mathrm{NaOH}$ solution, it is possible to obtain faujasite, phillipsite and/or sodalite by the changing the synthesis conditions. However, this type of process has a great potential due to the possibility of obtaining a low-cost material with high usefulness. Sodium zeolites obtained in the synthesis from natural or expanded perlite can be successfully used in the sorption processes, in particular heavy metals $[14,19,23,29,30]$ as well as cyanide ions [31]. Results of some studies [31,32] indicate a tenfold greater cation exchange capacity of synthetic zeolites with respect to the natural ones (e.g. clinoptilolite). If you use the waste material as a substrate, such a process takes on particular significance. It can be concluded that zeolityzation of aluminosilicate materials is a low cost method for the preparation of sorbents that can be used in wastewater treatment processes.

In this paper, the results of an experimental study on the formation of zeolites from expanded perlite waste in various concentrations of alkaline solutions as well as reaction temperature and time were reported. The aim of this study was to obtain suitable absorbent material for environmental applications, assuming the time and energy savings. The specific aims were to analyze the resulting products in terms of zeolite type. 


\section{Experimental}

The perlite waste used in the zeolitisation experiments was produced during separation of expanded perlite products from air classification (grains size $<0.4 \mathrm{~mm}$ ). XRD analysis confirmed that the compound contained amorphous aluminosilicate phase with a $\mathrm{SiO}_{2} / \mathrm{Al}_{2} \mathrm{O}_{3}$ molar ratio of 9.57. The synthesis was carried out by mixing the perlite with aqueous solution of sodium hydroxide (alternatively potassium or lithium hydroxide) in the concentrations range of 0.5 to $5.0 \mathrm{~mol} / \mathrm{dm}^{3}$. The solid-to-solution ratio was maintained at 1:15 $(\mathrm{g} / \mathrm{ml})$. The reactions were performed under atmospheric pressure. Different temperatures in the range of 30 to $90{ }^{\circ} \mathrm{C}$, for various durations: 1 to 72 hours, were used. The final solid products were recovered by filtration and washing with distilled water until the $\mathrm{pH}$ of the filtrate was below 10 . The samples were dried at a temperature not exceeding $80{ }^{\circ} \mathrm{C}$.

The alteration products were identified by means of Philips X-ray powder diffraction X'Pert system $\left(\mathrm{CuK}_{\alpha}\right.$ radiation). The measuring time was 4 hours per sample, in the 2 theta range of $10^{\circ}$ to $90^{\circ}$ and a step over $0.008^{\circ}$. In order to determine the quantitative composition with an estimate of amorphous phase content, $30 \%$ of corundum as internal standard was introduced into selected samples.

The existence of zeolite frameworks was confirmed by the analysis of the spectra in the middle infrared. The spectra were measured on Bruker VERTEX 70v vacuum FT-IR spectrometer using the standard $\mathrm{KBr}$ pellets methods. They were collected in the region of 4000 to $100 \mathrm{~cm}^{-1}$ after 128 scans at $4 \mathrm{~cm}^{-1}$ resolution.

The chemical compositions of perlite waste and resulting samples were determined by the wavelength dispersive X-ray fluorescence spectrophotometer (XRF), (Model Axios mAX $4 \mathrm{~kW}$, PANalytical).

\section{Results and discussion}

The effect of reaction temperature and time of the crystallization of zeolites synthesized from ex- panded perlite waste was examined under the fixed 1:15 solid/liquid ratio in a temperature range of 30 to $90{ }^{\circ} \mathrm{C}$. Table 2 shows the experimental conditions and reaction products obtained in $\mathrm{NaOH}$ solutions. Depending on temperature and $\mathrm{NaOH}$ concentration, the identified phases include zeolite Na- $\mathrm{P}_{1}$, zeolite $\mathrm{X}$, zeolite ZSM-20, zeolite A, zeolite ZK-5 and hydroxysodalite. The amount of the amorphous phase determined based on Rietveld analysis is in the range of 27 to $80 \%$, depending on reaction conditions.

An analysis of phase composition of the zeolitization products shows that the synthesis of zeolite is possible using the $\mathrm{NaOH}$ solution at a temperature of at least $60{ }^{\circ} \mathrm{C}$. Zeolite $\mathrm{X}$ appears as a crystal phase at the lowest analyzed temperature. This phase has been formed at $60^{\circ} \mathrm{C}$, although very small peak on the XRD pattern is visible after reaction of perlite with $5.0 \mathrm{M} \mathrm{NaOH}$ at $50{ }^{\circ} \mathrm{C}$. A phase coexisting with the zeolite $\mathrm{X}$ is zeolite ZSM20. A relative amount of these phases varies depending on the reaction conditions: the amount of ZSM-20 decreases with increasing temperature and concentration of $\mathrm{NaOH}$. ZSM-20 is believed to resemble faujasite type zeolite in certain structural aspects, one difference being its higher $\mathrm{Si} / \mathrm{Al}$ ratio [35]. The largest amounts of zeolite $\mathrm{X}$ can be obtained at $70{ }^{\circ} \mathrm{C}$ : at higher temperature its amount gradually decreases in favor of other phases. At this temperature $-70{ }^{\circ} \mathrm{C}$ - small amounts of zeolite $\mathrm{Na}$ $\mathrm{P}_{1}$ appear. The highest yield of zeolite $\mathrm{Na}-\mathrm{P}_{1}$ was obtained by the synthesis of $3.0 \mathrm{M} \mathrm{NaOH}$ at $90{ }^{\circ} \mathrm{C}$ for $24 \mathrm{~h}$. It can be said that the formation of Na-P was favored by 3.0 to $4.0 \mathrm{M} \mathrm{NaOH}(1: 15 \mathrm{~S} / \mathrm{L}$ ratio) at 70 to $90{ }^{\circ} \mathrm{C}$. When the reaction was carried out under the influence of $5.0 \mathrm{M} \mathrm{NaOH}$ and at $1: 15$ $\mathrm{S} / \mathrm{L}$ ratio at $90{ }^{\circ} \mathrm{C}$, perlite has been converted to a single phase of sodalite. This synthetic Na- $\mathrm{P}_{1}$ and hydroxysodalite were used as a standard for further analysis. The occurrences of major phase ranges are shown schematically in Fig. 1. It has been shown that at temperatures below $100{ }^{\circ} \mathrm{C}$ the most stable phase is zeolite Na-P1 [11]. In contrast to the sodalite, this phase typically crystallizes under milder conditions. It was suggested that at higher temperatures and $\mathrm{NaOH}$ concentrations, zeolite $\mathrm{Na}-\mathrm{P}_{1}$ is unstable and transforms into sodalite, 
Table 2. Experimental conditions and reaction products obtained in $\mathrm{NaOH}$ solutions.

\begin{tabular}{|c|c|c|c|}
\hline $\begin{array}{c}\text { Temp. } \\
{\left[{ }^{\circ} \mathrm{C}\right]}\end{array}$ & $\begin{array}{c}\mathrm{C}_{\mathrm{NaOH}} \\
{\left[\mathrm{mol} / \mathrm{dm}^{3}\right]}\end{array}$ & $\begin{array}{r}\text { Time } \\
{[\mathrm{h}]} \\
\end{array}$ & Reaction products* \\
\hline \multirow{6}{*}{60} & 3.5 & 24 & - \\
\hline & \multirow{3}{*}{4.0} & 24 & zeolite $\mathbf{X}$, zeolite ZSM-20 \\
\hline & & 48 & zeolite $\mathbf{X}$, zeolite ZSM-20 \\
\hline & & 72 & zeolite $\mathbf{X}$, zeolite ZSM-20, zeolite Na-P $\mathrm{P}_{1}$ \\
\hline & 4.5 & 24 & zeolite $\mathbf{X}$, zeolite ZSM-20 \\
\hline & 5.0 & 24 & zeolite $\mathbf{X}$, zeolite ZSM-20 \\
\hline \multirow{5}{*}{70} & 3.0 & 24 & - \\
\hline & 3.5 & 24 & zeolite $\mathbf{X}$, zeolite Na- $\mathrm{P}_{1}$ \\
\hline & 4.0 & 24 & zeolite $\mathbf{X}$, zeolite ZSM-20, zeolite Na-P 1 \\
\hline & 4.5 & 24 & zeolite $\mathbf{X}$, zeolite $\mathrm{ZSM}-20$, zeolite Na- $\mathrm{P}_{1}$, sodalite \\
\hline & 5.0 & 24 & zeolite $\mathbf{X}$, zeolite ZSM-20, zeolite Na- $\mathrm{P}_{1}$, sodalite, zeolite A \\
\hline \multirow{6}{*}{80} & 2.5 & 24 & - \\
\hline & 3.0 & 24 & zeolite $\mathrm{X}$, zeolite $\mathbf{N a - P _ { 1 }}$, zeolite $\mathrm{ZK}-5$ \\
\hline & 3.5 & 24 & zeolite $\mathbf{X}$, zeolite Na-P ${ }_{1}$, zeolite ZK-5 \\
\hline & 4.0 & 24 & zeolite $\mathbf{X}$, zeolite Na- $\mathrm{P}_{1}$, zeolite $\mathrm{ZK}-5$ \\
\hline & 4.5 & 24 & zeolite $\mathbf{X}$, zeolite Na-P ${ }_{1}$, zeolite ZK-5, sodalite \\
\hline & 5.0 & 24 & zeolite $\mathbf{X}$, zeolite Na-P $\mathrm{P}_{1}$, zeolite $\mathrm{ZK}-5$, sodalite, zeolite A \\
\hline \multirow{12}{*}{90} & 2.0 & 24 & - \\
\hline & 2.5 & 24 & zeolite $\mathrm{X}$, zeolite $\mathrm{Na}-\mathrm{P}_{1}$ \\
\hline & \multirow{2}{*}{3.0} & 24 & zeolite $X$, zeolite Na-P 1 , zeolite ZK-5 \\
\hline & & 72 & zeolite Na-P $\mathbf{P}_{1}$ \\
\hline & \multirow{2}{*}{3.5} & 24 & zeolite $X$, zeolite Na-P $\mathbf{P}_{1}$, zeolite $\mathrm{ZK}-5$ \\
\hline & & 72 & zeolite $\mathrm{X}$, zeolite Na-P $\mathbf{P}_{1}$ \\
\hline & \multirow{2}{*}{4.0} & 24 & zeolite $X$, zeolite Na-P ${ }_{1}$, zeolite ZK-5, sodalite \\
\hline & & 72 & zeolite $X$, zeolite $\mathbf{N a - P _ { 1 }}$, sodalite \\
\hline & \multirow{2}{*}{4.5} & 24 & zeolite $\mathrm{Na}-\mathrm{P}_{1}$, sodalite \\
\hline & & 72 & zeolite Na- $\mathrm{P}_{1}$, sodalite \\
\hline & \multirow{2}{*}{5.0} & 24 & sodalite \\
\hline & & 72 & sodalite \\
\hline
\end{tabular}

*Bold letters represent major products identified by XRD.

which is confirmed in the related literature [36]. Additionally, an intense peak derived from a zeolite ZK-5 can be seen in diffraction patterns of samples obtained at 80 to $90{ }^{\circ} \mathrm{C}$. Minor amounts of LTA also occur as a result of synthesis from the highest analyzed concentrations at a temperature of 70 and $80{ }^{\circ} \mathrm{C}$.

At a predetermined temperature mineralogical transformations result mainly from a change of the concentration of $\mathrm{NaOH}$, whereas the time and $\mathrm{S} / \mathrm{L}$ ratio seem to be less important for zeolite formation. It was also an attempt to optimize the time of synthesis. Exemplary XRD patterns are presented in Fig. 2. For the samples obtained at $90{ }^{\circ} \mathrm{C}$ using $5.0 \mathrm{M} \mathrm{NaOH}$ the first quantity of crystalline phase, zeolite $\mathrm{A}$, is detectable after $1 \mathrm{~h}$. Its quantity is greatest after $3 \mathrm{~h}$ and then gradually decreases: zeolite A completely disappears after $6 \mathrm{~h}$. At the same time sodalite crystallizes. It was confirmed that extending the synthesis time results in the transformation of the zeolite $\mathrm{X}$ and zeolite $\mathrm{A}$ into zeolite Na- $\mathrm{P}_{1}$ and sodalite $[1,21,36]$. Lengthening reaction time from 24 to $72 \mathrm{~h}$ resulted in slight increase in the amount of the resulting phases. However, at the same time qualitative changes could also be observed, e.g. the appearance of $\mathrm{Na}-\mathrm{P}_{1}$ at $60{ }^{\circ} \mathrm{C}$ as 


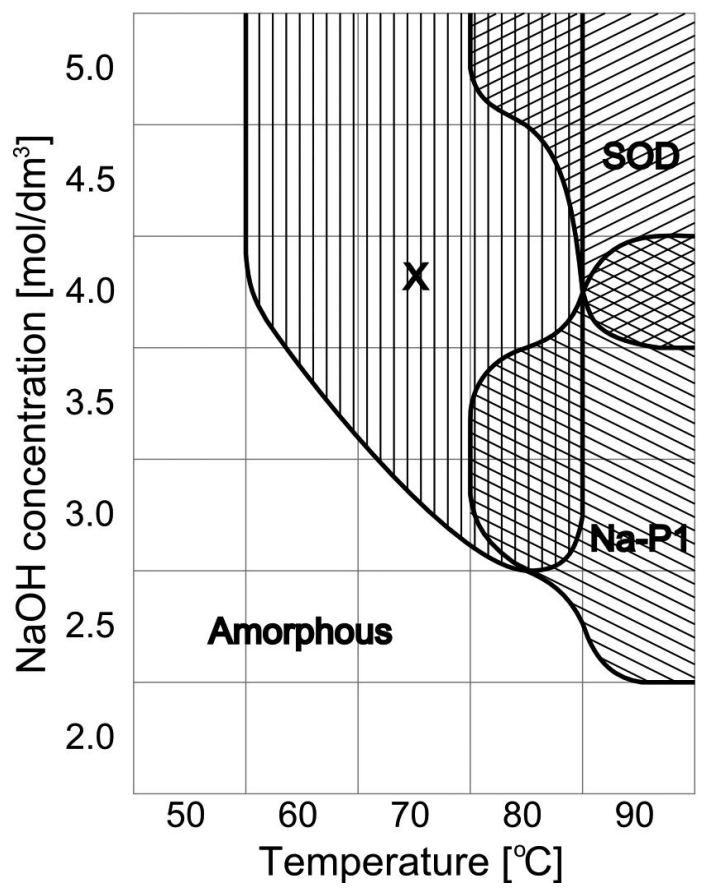

Fig. 1. Phase diagram of the main product of $24 \mathrm{~h}$ zeolitization as a function of temperature and concentration of $\mathrm{NaOH}$ solution.

well as disappearance of zeolite $\mathrm{ZK}-5$ at $90{ }^{\circ} \mathrm{C}$ (Table 1). Based on the obtained results it can be also assumed that synthesis of zeolites at a temperature lower than $60{ }^{\circ} \mathrm{C}$ probably is possible but may require much longer times than the analyzed $72 \mathrm{~h}$.

The presence of zeolite structures was confirmed by measurements in the mid-infrared range (Fig. 3). In the spectra of zeolites we can distinguish several groups of bands: the bands connected with the presence of $\mathrm{OH}^{-}$groups and zeolites water in the range of 3700 to $1600 \mathrm{~cm}^{-1}$; the bands originating from the internal vibrations of $\mathrm{Si}-\mathrm{O}(\mathrm{Si})$ and $\mathrm{Si}-\mathrm{O}(\mathrm{Al})$ bonds, in the range of 1200 to $400 \mathrm{~cm}^{-1}$; and the bands in the pseudolattice region of the spectra (800 to $500 \mathrm{~cm}^{-1}$ ), connected with vibrations of overtetrahedral building units (rings built from silicon and aluminum tetrahedra).

MIR spectra confirm zeolitization temperature limit of $50{ }^{\circ} \mathrm{C}$ (Fig. 3). Starting from $60{ }^{\circ} \mathrm{C}$ full width at half maximum (FWHM) of the bands derived from the aluminosilicate structure of the material decreases significantly. The de-
$1 \mathrm{~h}$
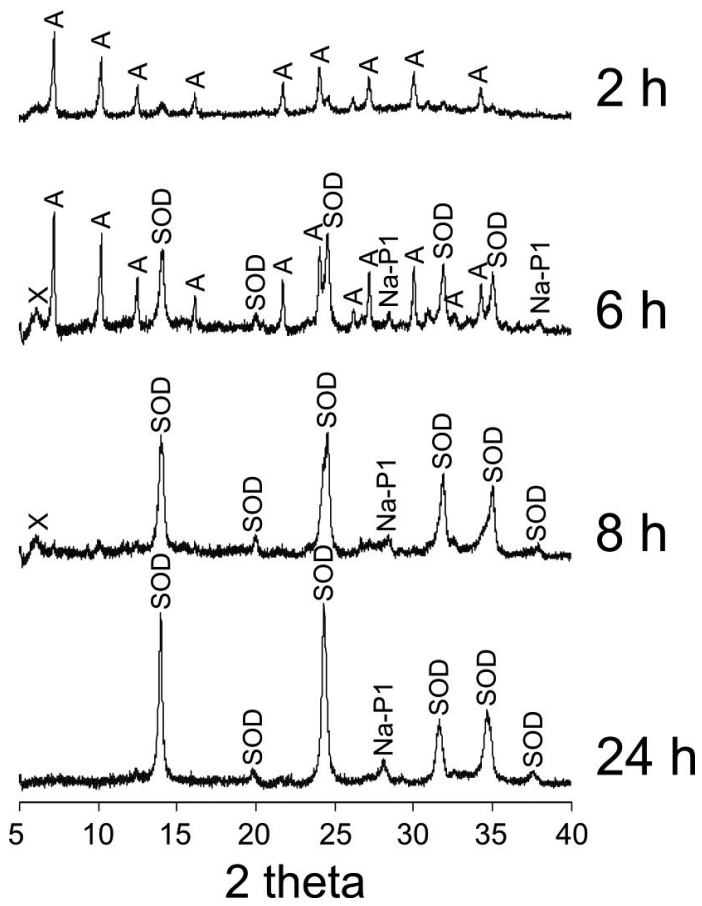

Fig. 2. XRD patterns of the samples obtained from $5.0 \mathrm{M} \mathrm{NaOH}$ at $90{ }^{\circ} \mathrm{C}$ depending on the synthesis time.

crease in FWHM of the most intense bands at about $1052 \mathrm{~cm}^{-1}$ indicates the increased proportion of crystalline phases with the synthesis temperature rise. At the same time, with the increase in temperature of the process, the band at about $1052 \mathrm{~cm}^{-1}$ shifts toward higher wave numbers. This situation indicates increasing share of aluminum in tetrahedral positions in comparison to the starting material because the length of $\mathrm{Al}-\mathrm{O}$ bond is greater than the $\mathrm{Si}-\mathrm{O}$ bond, and it is further characterized by lower force constant [37]. This indicates the first stage of the analyzed process, which is the dissolution of the raw material [38]; temperature rise (as well as $\mathrm{pH}$ of alkaline solution) causes a greater desilication of the perlite structure. This undoubtedly has an impact on the type of reaction products formed in the setpoint temperature. It can be seen that the position of the analyzed bands has not changed significantly for the samples obtained at temperatures 
above $60{ }^{\circ} \mathrm{C}$. For the product obtained above $80^{\circ} \mathrm{C}$ the band re-shift toward higher wave number is related to the emergence of the sodalite.

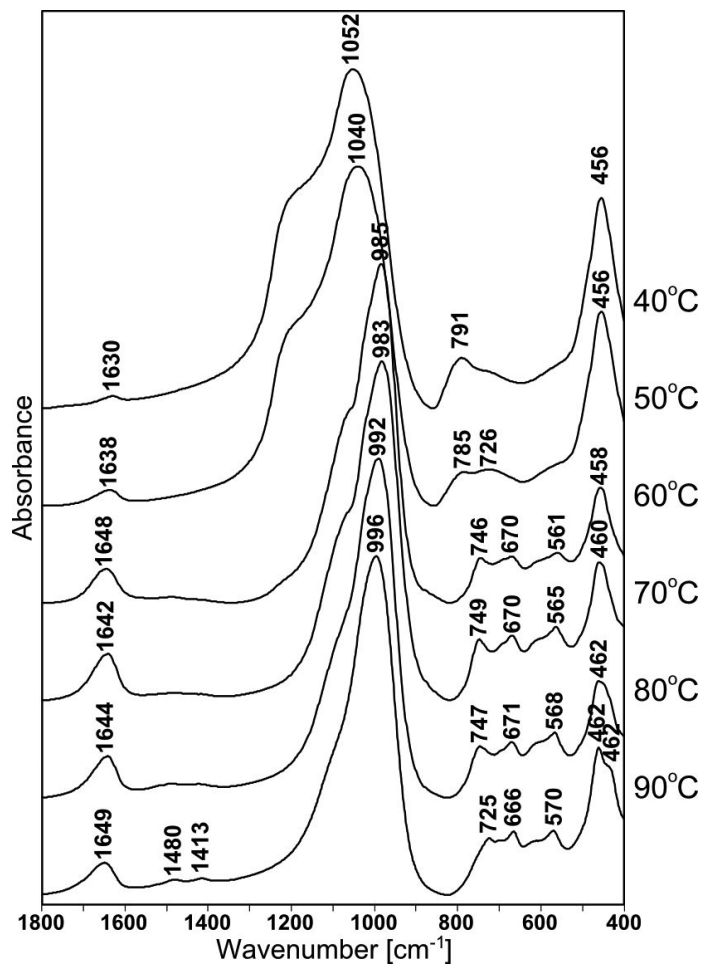

Fig. 3. MIR spectra of the samples obtained from $4.0 \mathrm{M}$ $\mathrm{NaOH}$ at $70^{\circ} \mathrm{C}$ and after $24 \mathrm{~h}$.

The bands associated with the characteristic ring vibrations can be observed in the pseudolattice region of the spectra (Fig. 4). Based on the sequence of arrangement of the bands in this range it is possible to identify a zeolite structure type [39]. The presence of bands at about 750 and $670 \mathrm{~cm}^{-1}$ is related to the vibrations of 6-membered rings, which occur both in the structure of zeolite $\mathrm{X}$ (Fig. 4a) and zeolite Na-P ${ }_{1}$ (Fig. 4b). The spectrum of the sample obtained at $90{ }^{\circ} \mathrm{C}$ using $5.0 \mathrm{M} \mathrm{NaOH}$ (Fig. 4c) is characterized by a group of three bands with a small FWHM: at 725, 702 and $663 \mathrm{~cm}^{-1}$, which clearly indicate the presence of sodalite.

In order to better understand the processes, other zeolite structures, using other alkaline solutions have been attempted to obtain at low temperature. It was found, that zeolitization of perlite waste did not occur in $\mathrm{KOH}$ solution. Obtaining potassium zeolites in the manner analogous to

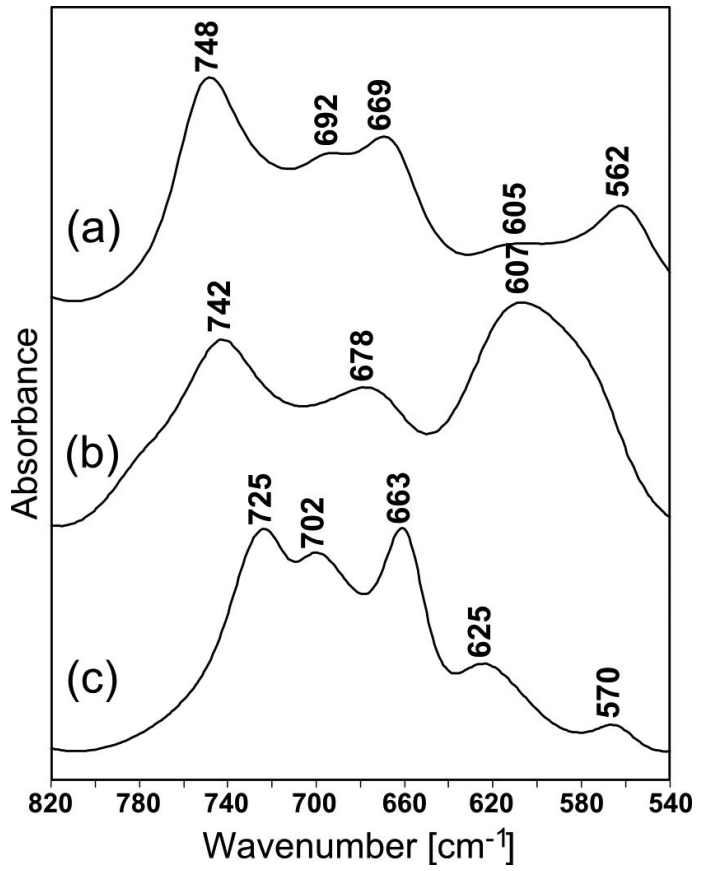

Fig. 4. MIR spectra of the samples whose main components are: zeolite $\mathrm{X}\left(5.0 \mathrm{M} \mathrm{NaOH}\right.$ at $\left.60{ }^{\circ} \mathrm{C}\right)$ (a) zeolite $\mathrm{Na}_{1} \mathrm{P}_{1}\left(3.0 \mathrm{M} \mathrm{NaOH}\right.$ at $\left.90{ }^{\circ} \mathrm{C}\right)$ (b) and sodalite $\left(5.0 \mathrm{M} \mathrm{NaOH}\right.$ at $\left.90{ }^{\circ} \mathrm{C}\right)(\mathrm{c})$.

the synthesis with the use of $\mathrm{NaOH}$, i.e. in temperature below $100{ }^{\circ} \mathrm{C}$ is not possible; however, there is the likelihood of obtaining of disordered structures. Exemplary MIR spectrum of the samples obtained from 5.0 M KOH is shown in Fig. 5b. No bands, which would indicate the presence of zeolite structures in the samples in the pseudolattice region of the spectrum, can be observed (compare Fig. 5c). The large FWHM of the bands indicates the presence of substantial amounts of amorphous phase. On the other hand, there are differences between the spectrum before (Fig. 5a) and after (Fig. 5b) treatment with KOH. High $\mathrm{pH}$ probably causes dissolution of the amorphous phase. The band at about $1056 \mathrm{~cm}^{-1}$ is shifted towards lower wavenumbers, which suggests decrease in $\mathrm{Si} / \mathrm{Al}$ ratio in comparison to the starting material. The new shoulder at $875 \mathrm{~cm}^{-1}$ can be assigned to $\mathrm{Al}-\mathrm{OH}$ stretching vibrations for aluminum in octahedral coordination [40]. The situation is different in the case of lithium hydroxide. A similar synthesis, with the use of $\mathrm{LiOH}$ solution, results in 
obtaining crystalline products: lithium silicate and small amounts of lithium carbonate. Ionic radius of the analyzed cations probably plays a decisive role; $\mathrm{K}^{+}$is characterized by relatively large ionic radius, and on the contrary, $\mathrm{Li}^{+}$is small and tends to tetrahedral coordination. Based on related literature it was found that $\mathrm{Na}^{+}$cations act as a template, therefore, the presence in the system of ions other than sodium will have no influence on the structure topology or this influence will be minimal [41].

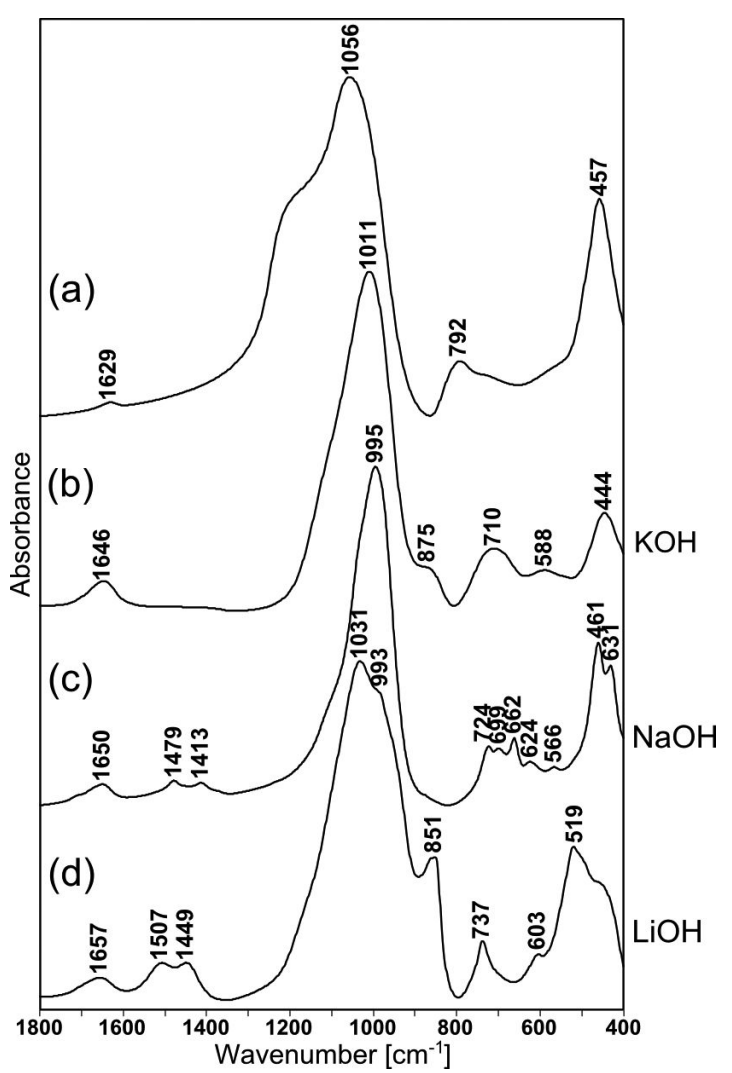

Fig. 5. MIR spectra of the initial perlitc waste (a) and the samples obtained from 5.0 M KOH (b), $\mathrm{NaOH}(\mathrm{c})$ and $\mathrm{LiOH}(\mathrm{d})$ at $90{ }^{\circ} \mathrm{C}$ and after $24 \mathrm{~h}$.

Obtaining zeolitic material with a good sorption capacity was one of the aims of this study. According to the literature data, synthetic zeolites Na- $\mathrm{P}_{1}$ and $\mathrm{X}$ [21] are characterized by about ten times higher sorption capacity than sodalite [42]. The volume of empty spaces in the structure is the second parameter that indirectly indicates a high sorption capacity of the material: for zeolite $\mathrm{X}-47 \%$, for zeolite Na-P $1-41 \%$, and for sodalite - only $35 \%$ [1]. For these reasons, zeolite $\mathrm{X}$ - without sodalite - is the most expected phase. In this work, the largest quantities of zeolite $\mathrm{X}$ were obtained by using a $4.0 \mathrm{M} \mathrm{NaOH}$ solution at $70{ }^{\circ} \mathrm{C}$.

The zeolitic materials synthesized under different conditions are characterized by a similar chemical composition (Table 3). Compared to the initial perlite waste, the chemical compositions of the reaction products have less $\mathrm{Si}$ and $\mathrm{K}$ and more $\mathrm{Na}, \mathrm{Ca}, \mathrm{Al}$ and $\mathrm{Fe}$. It was confirmed that in the whole temperatures range the amount of sodium taken up increases linearly with increasing amount of sodium present in the solution [18]. Sodium is the main exchangeable cation in the structure balancing the charge of the aluminosilicate lattice of zeolitic materials. From a temperature of $60{ }^{\circ} \mathrm{C}$ the samples have an excess of sodium in relation to the aluminum atoms. In addition to the zeolite structure and residual glassy phase, sodium is probably bound in carbonates, which was found by measuring the IR spectra (Fig. 3). The integral intensity of the bands connected with the presence of $\left(\mathrm{CO}_{3}\right)$ groups in the measured samples increases with the temperature rise. Exchangeable $\mathrm{K}^{+}, \mathrm{Ca}^{2+}$, and $\mathrm{Mg}^{2+}$ can balance up to $14 \%$ the zeolite charge. It is also confirmed that with increasing temperature the synthetic zeolites are enriched in $\mathrm{Na}, \mathrm{Ca}$ and $\mathrm{Mg}$ relative to $\mathrm{K}$ [18]. As shown above, potassium is not involved in creating the structure of the zeolite in the analyzed system, probably due to its large ionic radius.

It was found that the uptake of $\mathrm{Na}^{+}$ions is the highest in the products containing sodalite. At the same time, the amount of Si remaining in the solid phase decreases gradually. From the viewpoint of application of the material, significant share of aluminum in the structure is expected - low $\mathrm{Si} / \mathrm{Al}$ ratio (Table 3) results in a greater amount of cation exchange positions.

\section{Conclusions}

The expanded perlite waste is a promising material for the synthesis of zeolites. Analysis of the 
Table 3. Chemical composition (wt.\%) of initial perlite and zeolitic materials obtained in $4.0 \mathrm{M} \mathrm{NaOH}$ in $24 \mathrm{~h}$ synthesis process, at various temperatures.

\begin{tabular}{|c|c|c|c|c|c|c|c|c|c|}
\hline Sample & & Perlite & $30{ }^{\circ} \mathrm{C}$ & $40{ }^{\circ} \mathrm{C}$ & $50{ }^{\circ} \mathbf{C}$ & $60{ }^{\circ} \mathrm{C}$ & $70^{\circ} \mathrm{C}$ & $80^{\circ} \mathrm{C}$ & $90^{\circ} \mathrm{C}$ \\
\hline Zeolite phase content [ & [\%] & 0 & 0 & 0 & $\sim 0$ & $\sim 45$ & $\sim 60$ & $\sim 58$ & $\sim 62$ \\
\hline \multirow{9}{*}{ Chemical composition [\%] } & $\mathrm{SiO}_{2}$ & 75.39 & 74.87 & 74.22 & 66.84 & 40.22 & 40.46 & 41.10 & 38.21 \\
\hline & $\mathrm{Al}_{2} \mathrm{O}_{3}$ & 13.36 & 14.26 & 14.68 & 17.85 & 27.57 & 30.16 & 28.90 & 29.10 \\
\hline & $\mathrm{Na}_{2} \mathrm{O}$ & 4.61 & 5.58 & 5.66 & 9.82 & 28.38 & 24.92 & 25.25 & 27.96 \\
\hline & $\mathrm{K}_{2} \mathrm{O}$ & 4.11 & 3.13 & 3.08 & 2.57 & 0.73 & 0.72 & 1.11 & 0.34 \\
\hline & $\mathrm{Fe}_{2} \mathrm{O}_{3}$ & 1.22 & 0.89 & 1.06 & 1.30 & 1.33 & 1.73 & 1.72 & 2.10 \\
\hline & $\mathrm{CaO}$ & 0.97 & 0.75 & 0.91 & 1.19 & 1.29 & 1.65 & 1.50 & 1.82 \\
\hline & $\mathrm{MgO}$ & 0.11 & 0.12 & 0.14 & 0.16 & 0.22 & 0.17 & 0.18 & 0.18 \\
\hline & $\mathrm{TiO}_{2}$ & 0.07 & 0.05 & 0.06 & 0.08 & 0.08 & 0.08 & 0.09 & 0.09 \\
\hline & other & 0.16 & 0.35 & 0.17 & 0.19 & 0.18 & 0.11 & 0.16 & 0.20 \\
\hline \multicolumn{2}{|l|}{ Si/Al } & 4.79 & 4.45 & 4.29 & 3.18 & 1.24 & 1.14 & 1.21 & 1.11 \\
\hline \multicolumn{2}{|l|}{$\mathrm{Na} / \mathrm{Si}$} & 0.12 & 0.14 & 0.15 & 0.29 & 1.37 & 1.19 & 1.19 & 1.42 \\
\hline \multicolumn{2}{|l|}{$\mathbf{N a} / \mathbf{A l}$} & 0.57 & 0.64 & 0.64 & 0.91 & 1.69 & 1.36 & 1.43 & 1.58 \\
\hline \multicolumn{2}{|l|}{$\mathrm{K}+2 \mathrm{Ca}+2 \mathrm{Mg} / \mathrm{Al}$} & 0.49 & 0.35 & 0.37 & 0.30 & 0.13 & 0.14 & 0.15 & 0.14 \\
\hline \multicolumn{2}{|l|}{$\left(\mathrm{Me}^{+}+2 \mathrm{Me}^{2+}\right) /(\mathrm{Si}+\mathrm{Al})$} & 0.18 & 0.18 & 0.19 & 0.29 & 0.82 & 0.70 & 0.72 & 0.82 \\
\hline
\end{tabular}

data showed that the zeolitization process is efficient only at temperatures exceeding $50{ }^{\circ} \mathrm{C}$. Lower temperatures probably are possible but may require much longer times to achieve good yield of the desired product. At the analyzed temperatures, the most stable phase is zeolite Na- $\mathrm{P}_{1}$. As a result of the reaction at lower analyzed concentrations of $\mathrm{NaOH}$ solution, phase co-occurring with zeolite Na- $\mathrm{P}_{1}$ is zeolite $\mathrm{X}$, whereas at high concentrations of hydroxide, hydroxysodalite is formed in large quantities.

Based on the analysis of the phase composition of the zeolitization products, i.e. the highest content of zeolite $\mathrm{X}$, it has been found that a material characterized by potentially best sorption capacity can be obtained using a $4.0 \mathrm{M} \mathrm{NaOH}$ solution at $70{ }^{\circ} \mathrm{C}$ and process duration of $24 \mathrm{~h}$. The tightening of the synthesis conditions, i.e. increase of any these parameters, results in obtaining sodalite, which is not preferred due to the assumption of this work. On the other hand, samples, which were obtained at higher temperatures, have lower $\mathrm{Si} / \mathrm{Al}$ molar ratio and thus potentially higher cation exchange capacity.

\section{Acknowledgements}

This work is financial supported by The National Centre for Research and Development (NCBiR) under grant no. PBS1 177206.

\section{References}

[1] BRECK D.W., Zeolite Molecular Sieves, John Wiley \& Sons, New York - London - Sydney - Toronto, 1974.

[2] Colella C., Natural zeolites, in: ČEJKA J., BeKKUM H. (Eds.), Zeolites and ordered mesoporous materials: Progress and prospects, Studies in Surface Science and Catalysis 157, Elsevier, 2005, p. 13.

[3] Gottardi G., Galli E. (Eds.), Natural Zeolites, Mineral and Rocks 18, Springer-Verlag, Berlin Heidelberg, 1985.

[4] Barrer R.M., White E.A.D., J. Chem. Soc. (Resumed), (1952), 1561.

[5] Zhdanov S.P., Khvoshchev S.S., Feoktistova N.N., Synthetic Zeolites, Gordon and Breach Science, 1990, p. 1.

[6] Williams C.D., Zeolites, in: KING R.B., Encyclopedia of Inorganic Chemistry, John Wiley \& Sons, Athens, USA, 1994, p. 4363.

[7] Georgiev D., Bogdanov B., Angelova K., MARKOVSKA I., Hristov Y., Synthetic zeolites structure, classification, current trends in zeolite synthesis. Review, International Science Conference, 4 5.06.2009, Stara Zagora, Bulgaria.

[8] www.perlite.info.

[9] www.schundler.com.

[10] Noh J.W., Boles J.R., Clay. Clay. Miner., 37 (1989), 47.

[11] Khodabandeh S., Davis M.E., Micropor. Mater, 9 (1997), 161.

[12] Gonthier S., Gora L., Güray I., Thompson R.W., Zeolites, 13 (1993), 414.

[13] Barth-Wirsching U., Höller H., Klammer D., Konrad B., Miner. Petrol., 48 (1993), 275.

[14] Dyer A., Tangkawanit S., Rangsriwatananon K., Micropor. Mesopor. Mat., 75 (2004), 273. 
[15] Kongkachuichay P., Lohsoontorn P., Science Asia, 32 (2006), 13.

[16] TANGKaWAnit S., RangsriWatananon K., Suranaree J. Sci. Technol., 12/1 (2005), 61.

[17] Gualtieri A.F., Phys. Chem. Miner., 28 (2001), 719.

[18] Christidis G.E., Phapaliars I., Kontopoulos A., Appl. Clay Sci., 15 (1999), 305.

[19] TangKaWanit S., Synthesis of zeolites from perlite and study of their ion exchange properties, Suranaree University of Technology, 2004.

[20] Rujiwatra A., Mater. Lett., 58 (2004), 2012.

[21] Christidis G.E., Papantoni H., Open Mineral. J., 2 (2008), 1.

[22] Phosawat W., ChareonPanich M., Sudasna-NAAYUdThyA P., Production of Zeolite Y from perlite, online: http://kucon.lib.ku.ac.th/.

[23] Christidis G.E., Galani K., Markopoulos T., Synthesis of high added value zeolites from perlite and expanded perlite waste materials, in: SCOTT P.W., BRISTOW C.M. (Eds.), Industrial Minerals and Extractive Industry Geology, The Geological Society Publishing House, UK 2002, p. 345.

[24] Psycharis V., Perdikatsis V., Christidis G., Crystal structure and Rietveld refinement of zeolite A synthesized from fine-grained perlite waste materials, Bulletin of the Geological Society of Greece 36 - Proceedings of the $10^{\text {th }}$ International Congress, Thessaloniki, April 2004, p. 121.

[25] Burriesci N., CRisafulli M.L., SAiJA L.M., Mater. Lett., 2/1 (1983), 74.

[26] Kawano M., Tomita K., Clay. Clay Miner., 45/3 (1997), 365

[27] Hawkins D.P., Clay. Clay Miner., 29/5 (1981), 331.

[28] Burriesci N., Crisafulli M.L., Giordano N., BART J.C.J., Polizzotti G., Zeolites, 4/4 (1984), 384.
[29] Moirou A., Vaxevanidou A., Christidis G.E. Paspaliaris I., Clay. Clay Miner, $48 / 5$ (2000), 563.

[30] Tangkawanit S., Rangsriwatananon K., Dyer A., Micropor. Mesopor. Mat., 79 (2005), 171.

[31] Faghihian H., Kamali M., Int. J. Environ. Pollut., 19/6 (2003), 557.

[32] Ciciszwili G.W., Andronikaszwili T.G., Kirow G.N., FlizowA L.D., Zeolity naturalne (in Polish), WNT, Warszawa, 1990.

[33] Wirsching U., Clay. Clay Miner., 29 (1981), 171.

[34] Khodabandeh S., Davis M.E., Chem. Commun., (1996), 1205.

[35] Dwyer J., Millward D., O’Malley P.J., Araya A., Corma A., Fornes V., Martinez A., J. Chem. Soc., Faraday Trans., 86/6 (1990), 1001.

[36] Novembre D., Di Sabatino B., Gimeno D., PaCE C., Clay Miner., 46 (2011), 339.

[37] Fernández-Jiménez A., Palomo A., Micropor. Mesopor. Mat., 86 (2005), 207.

[38] Cundy C.S., Cox P.A., Micropor. Mesopor. Mat., 82 (2005), 1.

[39] Mozgawa W., J. Mol. Struct., 596 (2001), 129.

[40] McMillan P., Piriou B., Navrotsky A., Geochim. Cosmochim. Ac., 46 (1982), 2021.

[41] WiLson S.T., Templating in molecular sieve synthesis, in: RoBSON H. (ed.), Verified syntheses of zeolitic materials, Elsevier, Amsterdam - London - New York Oxford - Paris - Shannon - Tokyo, 2001, p. 27.

[42] Querol X., Moreno N., Umaña J.C., Alastuey A., Hernández E., López-Soler A., Plana F., Int. J. Coal Geol., 50 (2002), 413.

Received 2014-04-17 Accepted 2014-06-06 